\title{
ASSESSING THE SYSTEMIC RISK BETWEEN AMERICAN AND EUROPEAN FINANCIAL SYSTEMS
}

\section{Ayhan Orhana, Vahit Ferhan Benli $^{b}$, Rui Alexandre Castanhoc}

\begin{abstract}
The present study focuses on the analysis of systemic risk in the American and European financial systems for the period from 20 August 2004 to 28 February 2014. The global crisis in 2007 has brought attention to the urgent need to understand the systemic risk issues and the stability of financial systems along with their actors. To assess systemic risk, Adrian and Brunnermeier (2011) advocated the use of conditional value-at-risk $(\mathrm{CoVaR})$ methodology in integrating quantile regression. Instead of the value-at-risk (VaR), which is unable to detect systemic risk, we seek to use the CoVaR methodology to calculate the systemic risk levels of the United States and European markets. In the light of related findings, we conclude that the insurance sector contributes most to the systemic risk in the USA, while in the Eurozone, it is the financial services sector that is highly interconnected with systemic risk.
\end{abstract}

Keywords: Systemic risk, financial regulation and management, value-at-risk, CoVaR, quantile regression

\section{JEL Classification: E50, E51, G20, H12}

\section{Introduction}

The financial system has always played a pivotal role in the proper functioning of modern economies. Nevertheless, the recent financial crisis of 2007 clearly shows that its failure can be harmful to the interconnected network economies. This has prompted researchers and regulators to become aware of the insecurity of the financial systems and the seriousness of the vulnerabilities to "systemic risks". The damage inherent in this risk is felt dramatically only after it has materialized. In this sense, vigilance must be exercised in the continuous supervision of the financial system and the timely analysis of the signals raised according to Schwaab (2011).

\footnotetext{
a Kocaeli University, Department of Economics, Koaceli, Turkey

b İstanbul Commerce University, Banking and Finance Department, Istanbul, Turkey

c WSB University, Faculty of Applied Sciences, Dabrowa Gornicza, Poland Email: acastanho@wsb.edu.pl
} 
Contextually, this paper aims at gaining insight into the systemic risk issues of the US and EU financial systems. It comprises eight main sections: Sections 1 to 3 are devoted to the explanation of the concept of systemic risk and they address the regulatory reform component to minimize it. Sections 4 and 5 describe the evolution of risks as well as the measures relating to each type. Section 6 is dedicated to the presentation of the data and the methodology considered. Section 7 reports the results obtained, accompanied by their interpretations and finally Section 8 concludes.

\section{Systemic Risk and Financial Regulation}

\subsection{Systemic risk}

Systemic risk is often recognized as a "hard-to-define-but-you-know-it-when-you-see-it" concept. To understand this notion properly, we need to take a look at its definitions that are proposed in the literature. Following the studies of the Financial Stability Board (FSB), International Monetary Fund (IMF) and Bank for International Settlements (BIS) for the G-20, the systemic risk can be identified as "a risk of disruption to financial services that is caused by an impairment of all or parts of the financial system and has the potential to have serious negative consequences for the real economy".

Mishkin (2008) defines systemic risk as a sudden event that shakes financial markets and prevents them from efficiently channelling capital where investment opportunities are best. The European Central Bank (2009) defines systemic risk as a risk of financial instability to the detriment of the functioning of the financial system to such an extent that economic growth and well-being suffer significantly.

According to Lepetit (2010), financial instability resulting from total or partial deterioration of the components of the financial system can have a negative impact on the real economy. In this respect, we can define a key element of systemic risk, namely the enhancement of fragility inside the financial system. This symmetric shock transmission capability is described in the sense that a contagious shock in a highly "institutional way" is transmitted from one SIFI (systemically important financial institution) to another, causing financial imbalance to the entire financial system. This interaction and interconnectedness between the various institutions on the one hand and between the financial and economic spheres on the other is due to the contagion phenomenon studied in finance since the 1990s.

In the same context, Dirk (2010) has described this financial contagion as a phenomenon resulting in the occurrence of a shock shaking one or more markets, countries or institutions and spreading to other markets, countries or institutions. However, this main risk transformation mechanism is often under-estimated or even neglected by professionals and regulators when quantifying the risk. 


\subsection{Systemic approach to financial regulation}

In fact, one of the biggest challenges for regulators and public authorities today is restoring financial and economic stability. Borio and Drehmann (2009) and Gauthier (2012) stressed the need for a radical change in the current regulation, called micro-prudential, by integrating the issues related to systemic risk. Since then, macro-prudential regulation has emerged. Indeed, the financial system is the scope of macro-prudential regulation. Nevertheless, the micro-prudential regulation is concerned with the different financial institutions controlled individually. Thus, the fragility of the financial system and its role in triggering systemic crises has led many regulatory institutions to monitor and regulate the systemic risk on a regular basis. In 2010, the International Organization of Securities Commissions (IOSCO) set up a research department whose role is to monitor, mitigate and manage systemic risk by analysing the scope of regulation on a continuous basis (Barr et al., 2016).

Having identified the need for global regulation of systemic risks, the supraregulatory bodies among G-20, especially the FSB (Financial Stability Board), charged with coordinating domestic post-crisis reforms, is mandated to address "vulnerabilities affecting financial systems in the interest of financial stability". The FSB and the BCBS are the primary institutions to resolve and to set the tone of voice in developing of specific tools against a build-up of systemic risk in the financial system. One of the key efforts of FSB has been the designation of major dealer banks as being "systematically important" (Darr, 2011). In this context, those dealer banks are also referred as "large complex financial institutions" or as "Too Big to Fail (TBTF)", whose failure would pose a significant risk to the entire financial system domestically and also globally. Those major financial conglomerates, whose failure may jeopardize the entire financial system and the real economy, are entitled SIFIs (systematically important financial institutions)

(BCBS, 2011). SIFIs are sizable, globally well connected and complex financial entities, comprising of financial institutions, banks and corporations. They are also subdivided into global systematically important financial institutions (G-SIFIs), global systematically important banks (G-SIBs) and domestic systematically important banks (D-SIBs). A D-SIB is a bank whose default may cause damaging impact on the local economic and financial system in a country. A variety of metrics are developed by supranational governmental entities to designate a financial institution as a SIFI. Basel Committee's methodology for assessing the systemic importance of G-SIFIs relies on indicator-based measurement approach (BCBS, 2020: 19; Deloitte, 2013). According to this methodology, a G-SIB is designated on its footprints on cross-border activity, size, interconnectedness, substitutability and complexity. The same criteria are used by the FED 
for designation purposes. The financial governance of the SIFIs is therefore subject to enhanced supervision and regulation, including through the imposition of higher capital requirements, higher loss absorbency requirements, stress tests, additional group-wide resolution planning and higher level of risk management functions and implementation standards, which are very unconventional for ordinary financial institutions.

In fact, this regulatory reform has not yet found its way into the official language of banking supervisors since some authorities are considering it as finalization of the Basel III framework (Basel III set of regulations to contain systemic risks). Basel III introduced the concepts of global systemically important banks (G-SIBs) and domestic systematically important banks (D-SIBs) as carriers of systemic risks and demanded surcharges for those systematically important institutions to increase their loss absorption capacities. Higher capital requirements for those well-connected financial institutions aim to reduce the systemic risks by holding high capital buffers and avoid ex-post strong externalities causing financial systems to collapse (Freixas et al., 2015, p. 274). The recalibration of Basel III into a full-fledged new regulatory framework and its implementation as Basel IV will be completed in the transition period of 2017-2027 (BCBS, 2017).

Hence, it is crucial to monitor and analyse on a steady basis the economic and financial situation in order to diagnose systemic risk and implement the convenient measures pertaining to good financial governance.

\section{Evolution of Different Risk Measures}

In 1952, the modern theory of portfolio was born with the publication of the founder Harry Markowitz. A few decades later, in 1976, Ross developed an alternative to the CAPM called "Arbitrage Pricing Theory" (APT), based on a multi-factorial model (multi-beta). In 1992, Fama and French developed another multi-factorial model. According to Dowd (2005), these methods are not highly recommended for calculating market risk per se. The standard deviation and the betas do not allow considering the market risk satisfactorily. Hence, the publication of the Value-at-Risk (VaR) method in the early 1990s paved the way for the measurement of market risk. $\operatorname{VaR}(t, q)$ is defined as:

$$
\mathrm{P}\left(X^{i} \leq \operatorname{VaR}^{i}(t, q)\right)=q
$$

Where:

$q$ probability of adverse event where coverage rate, usually set at $1 \%$ or $5 \%$

$X^{i}$ represents the loss; it is a positive or negative random variable.

In 2011, Tobias Adrian, Senior Vice President and Head of Capital Markets at the FED New York, and Markus K. Brunnermeier, Professor at Princeton, proposed a new systemic 
risk measure named CoVaR. These two researchers intuitively added the prefix Co- to VaR, which designates the contagion.

$\mathrm{CoVaR}_{q}^{(i j)}$ is written as follows:

$\mathrm{P}\left(X^{i}=\operatorname{CoVaR}_{q}^{(i j)} \mid X^{j}=\operatorname{VaR}_{q}^{j}\right)=q$

$\operatorname{CoVaR}_{q}{ }^{(i j)}$ is defined as the $\operatorname{VaR}$ for an institution $i$ (or loss) under the effect of an event $C\left(X^{j}\right)$ of an institution $j$. This event is linked to the fact that the institution $j$ reaches its level of $\mathrm{VaR}$ such that: $X^{j}=\operatorname{VaR}_{q}^{j}$.

\section{Estimation of CoVaR on the American and European Markets}

\subsection{Motivation}

In our study, we opt for an approach combining studies already conducted on the financial sectors (cross-sectoral study) and financial institutions (inter-company study), distinguishing between life and non-life insurance. Subsequently, we plan to determine the CoVaR for two distinct regions: the United States and the Eurozone. Our goal is to guide the macroprudential regulatory actors towards sectors and institutions whose role is predominant in triggering systemic risk. This last is widespread and the impact of the financial system instability is more extensive and complex at the national, regional and international levels.

Figure 1: Global systemic risk by country (SRISK in billions of USD)

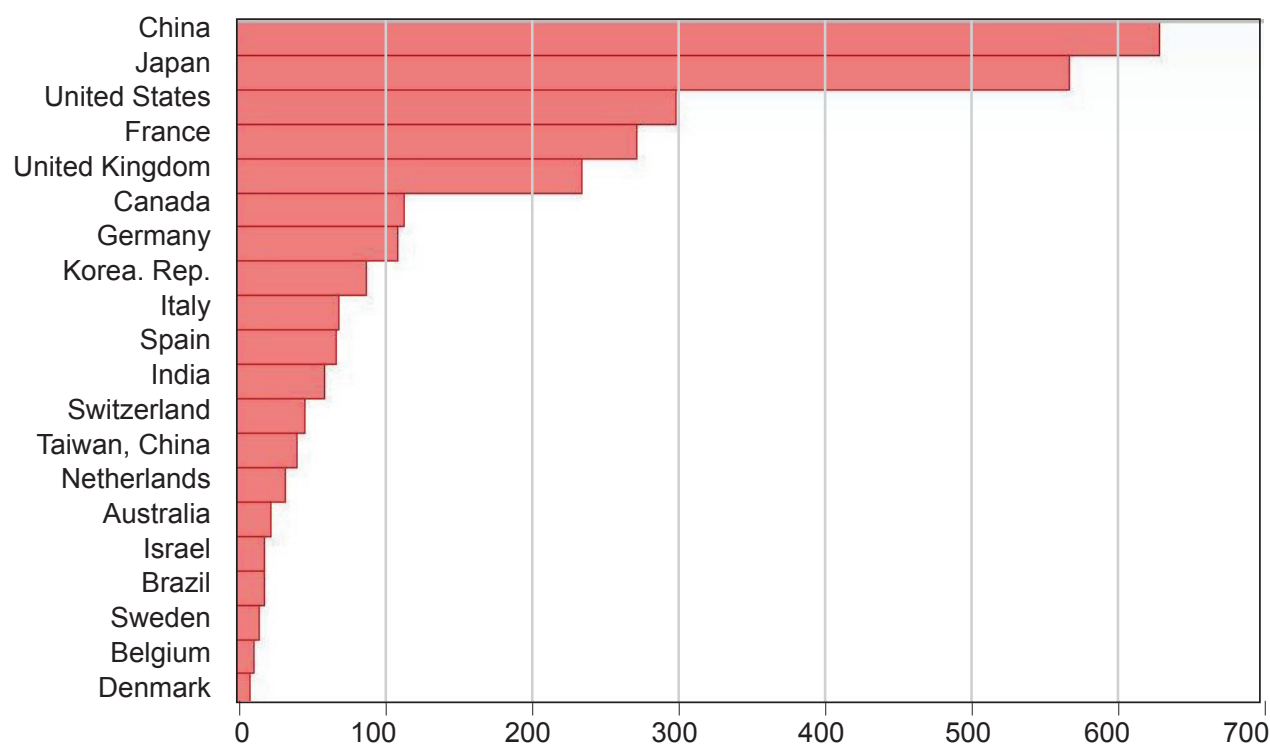

Source: http://vlab.stern.nyu.edu/welcome/srisk 
Figure 1 is developed by the V-Lab (Volatility Laboratory) on 31 December 2017, ranking country contributions to systemic risk globally. We notice clearly that the United States ranks third before France. As for the countries of the Eurozone, we can cite, in decreasing order of contribution, France, Germany, Italy, Spain, the Netherlands and Belgium.

\section{Financial Governance and the Institutionalization of Systemic Risks by SIFIs}

Having identified the need for global regulation of systemic risks, the supra-regulatory bodies among G-20, especially the FSB (Financial Stability Board), charged with coordinating domestic post-crisis reforms, is mandated to address "vulnerabilities affecting financial systems in the interest of financial stability" (Barr et al., 2016). The FSB and the BCBS are the primary institutions to resolve and to set the tone of voice in developing of specific tools against a build-up of systemic risk in the financial system. One of the key efforts of FSB has been the designation of major dealer banks as being "systematically important". In this context, those dealer banks are also referred as "large complex financial institutions" or as "Too Big to Fail (TBTF)", whose failure would pose a significant risk to the entire financial system domestically and also globally (Duffie, 2010). Those major financial conglomerates whose failure may jeopardize the entire financial system and the real economy are entitled SIFIs (systematically important financial institutions). SIFIs are sizable, globally well connected and complex financial entities, comprising of financial institutions, banks and corporations.

They are also subdivided into global systematically important financial institutions (G-SIFIs), global systematically important banks (G-SIBs) and domestic systematically important banks (D-SIBs) (Global Systematically Important Banks, 2011). A D-SIB is a bank whose default may cause damaging impact on the local economic and financial system in a country. A variety of metrics are developed by supra-national governmental entities to designate a financial institution as a SIFI. According to a methodology developed by BCBS, a G-SIB is designated on its footprints on cross-border activity, size, interconnectedness, substitutability and complexity (Deloitte, 2013). The same criteria are used by the FED for designation purposes. The financial governance of the SIFIs is therefore subject to enhanced supervision and regulation, including through the imposition of higher capital requirements, higher loss absorbency requirements, stress tests, additional group-wide resolution planning and higher level of risk management functions and implementation standards, which are very unconventional for ordinary financial institutions. 


\section{Presentation of Data}

Data on the US and European market at a daily frequency cover the period from 20 August 2004 to 28 February 2014, i.e., 2314 observations. We will present the variables needed to estimate CoVaR, referring mainly to Adrian and Brunnermeier (2011) and Bernal et al. (2013).

\subsubsection{American market}

\section{Sector indices:}

The financial sectors are represented by specific indices, mentioned in Table 1.

Table 1: Overview of sector indices, USA

\begin{tabular}{|c|c|c|c|c|}
\hline Sector & Notation & Data & Source & Measure \\
\hline Banks & DJUSBK & $\begin{array}{l}\text { Dow Jones U.S. Banks } \\
\text { index }\end{array}$ & \multirow{4}{*}{$\begin{array}{l}\text { Thomson } \\
\text { Reuters }\end{array}$} & \multirow{5}{*}{$\begin{array}{l}R_{t}^{j}=\text { Performance } \\
\text { of indices } \\
\ln \left(P_{t}\right)-\ln \left(P_{t-1}\right) \\
P_{t} \text { : asset price at date } t\end{array}$} \\
\hline Life Insurance & DJUSLI $_{t}$ & $\begin{array}{l}\text { Dow Jones U.S. } \\
\text { Life Insurance index }\end{array}$ & & \\
\hline $\begin{array}{l}\text { Non-life } \\
\text { insurance }\end{array}$ & DJUSNLI & $\begin{array}{l}\text { Dow Jones U.S. } \\
\text { Non-Life insurance Index }\end{array}$ & & \\
\hline $\begin{array}{l}\text { Financial } \\
\text { services }\end{array}$ & DJUSFS & $\begin{array}{l}\text { Dow Jones U.S. } \\
\text { Financial Services index }\end{array}$ & & \\
\hline System & S\&P 500_exFin & $\begin{array}{l}\text { S\&P } 500 \text { Ex-Financial } \\
\text { index }\end{array}$ & Bloomberg & \\
\hline
\end{tabular}

Source: Thomson Reuters \& Bloomberg Statistics

The financial industry contains the banking, insurance (life and non-life) and financial services sectors. For the system, the Dow Jones Index did not provide such an index. That is why we recommend using a more general index, the S\&P 500 Ex-Financial index.

\section{Financial institutions:}

For each of the financial sectors studied, we will identify the financial institutions with the largest market capitalization on 28 February 2014, according to Thomson Reuters, presented in Table 2 . 
Table 2: Overview of financial institutions, USA

\begin{tabular}{|c|c|c|c|}
\hline Sector & Notation & Institution & $\begin{array}{c}\text { Stock market capitalization } \\
\text { (millions of USD) }\end{array}$ \\
\hline \multirow{2}{*}{ Banks } & WFG & Wells Fargo & 257.651 \\
\hline & JPM & JP Morgan Chase & 209.013 \\
\hline \multirow{2}{*}{ Life Insurance } & MET & Met Life & 57.689 \\
\hline & PR & Prudentiel Financial & 39.353 \\
\hline \multirow{2}{*}{ Non-Life Insurance } & AIG & American International Group & 74.785 \\
\hline & $\mathrm{BH}$ & Berkshire Hathaway & 310.653 \\
\hline \multirow{2}{*}{ Financial Services } & GS & Goldman Sachs Group & 71.124 \\
\hline & $\mathrm{AE}$ & American Express & 92.218 \\
\hline
\end{tabular}

Source: Thomson Reuters \& Bloomberg Statistics

These institutions are used for the calculation of the sectoral indices mentioned above.

\section{Control variables:}

Adrian and Brunnermeier (2011) defined 7 control variables for estimating VaR and CoVaR on the US market, namely: VIX, which is a volatility index, listed in Chicago Board Options Exchange, Liquidity Spread short-term liquidity spread, the variation of the US sovereign bond rate of the same maturity, Yield Spread, Credit Spread, US equity market return, and finally the performance of the US real estate sector.

Table 3 shows the daily data necessary for the calculation of the control variables.

Table 3: Essential data for control variables, USA

\begin{tabular}{|c|c|c|}
\hline Data & Notation & Source \\
\hline American repo rate (3 months) & USSR & Thomson Reuters \\
\hline Rate of US Treasury Bond (maturity) & UST_Bill & Thomson Reuters \\
\hline Credit Spread for the US Market (10 years) & $U S C D S P_{t}$ & Bloomberg \\
\hline VIX Share Price & \multirow{3}{*}{$P_{t}$} & Thomson Reuters \\
\hline Dow Jones Real Estate Stock Price & & Thomson Reuters \\
\hline Stock Market Price S\&P 500 & & Thomson Reuters \\
\hline
\end{tabular}

Source: Thomson Reuters \& Bloomberg Statistics

The control variables are listed in Table 4. 
Table 4: Overview of control variables, USA

\begin{tabular}{|c|c|c|}
\hline Notation & Variable & Measure \\
\hline$V I X_{t}$ & VIX & $\ln \left(P_{t}\right)-\ln \left(P_{t-1}\right)$ \\
\hline$U_{S L Q S P}$ & Liquidity Spread & $\boldsymbol{U S S R}_{\boldsymbol{t}}$ (3months) - UST_Bill (3months) \\
\hline TBSP $_{t}$ & Bond rate variation & UST_Bill (3months) - UST_Bill $_{t-1}$ (3months) \\
\hline USYDSP $_{t}$ & Yield Spread & UST_Bill $(10$ years) - UST_Bill (3months) \\
\hline$U_{S C D S P}$ & Credit Spread(10 years) & \\
\hline$S \& P 500_{t}$ & Performance of S\&P 500 & $\ln \left(P_{t}\right)-\ln \left(P_{t-1}\right)$ \\
\hline DJUSRE $_{t}$ & Dow Jones Real Estate Return & $\ln \left(P_{t}\right)-\ln \left(P_{t-1}\right)$ \\
\hline
\end{tabular}

Source: CNB, Authors Calculations

\subsubsection{European market}

\section{Sector indices:}

Like the US market, the sector-specific indices of selected European countries are mentioned in Table 5.

Table 5: Overview of sector indices, Eurozone

\begin{tabular}{|c|c|c|c|c|}
\hline Sector & Notation & Data & Source & Measure \\
\hline Banks & $E S B K_{t}$ & Euro Stoxx Banks Index & \multirow{4}{*}{$\begin{array}{l}\text { Thomson } \\
\text { Reuters }\end{array}$} & \multirow{5}{*}{$R_{t}^{j}=\ln \left(P_{t}\right)-\ln \left(P_{t-1}\right)$} \\
\hline Life Insurance & $E_{t}$ & $\begin{array}{l}\text { Euro Stoxx Life insurance } \\
\text { Index }\end{array}$ & & \\
\hline $\begin{array}{l}\text { Non-life } \\
\text { insurance }\end{array}$ & $E S N L I_{t}$ & $\begin{array}{l}\text { Euro Stoxx Non-Life insurance } \\
\text { Index }\end{array}$ & & \\
\hline $\begin{array}{l}\text { Financial } \\
\text { services }\end{array}$ & ESFS $_{t}$ & $\begin{array}{l}\text { Euro Stoxx Financial Services } \\
\text { Index }\end{array}$ & & \\
\hline System & SE 600_exFin & $\begin{array}{l}\text { STOXX Europe } 600 \text { ex_ } \\
\text { Financials Index }\end{array}$ & Bloomberg & \\
\hline
\end{tabular}

Source: Thomson Reuters \& Bloomberg Statistics

It should be noted that these indices are exclusively related to 18 countries belonging to the European Union (Austria, Belgium, Cyprus, Estonia, Finland, France, Germany, 
Greece, Ireland, Italy, Latvia, Luxembourg, Malta, the Netherlands, Portugal, Slovakia, Slovenia and Spain).

\section{Financial institutions:}

We identified the financial institutions operating in the Eurozone member countries, with the largest market capitalization on 28 February 2014, according to Thomson Reuters, listed in Table 6.

Table 6: Overview of financial institutions, Eurozone

\begin{tabular}{|c|c|c|c|c|}
\hline Sector & Notation & Institution & Country & $\begin{array}{l}\text { Stock market capitalization } \\
\text { (millions of USD) }\end{array}$ \\
\hline \multirow{2}{*}{ Banks } & BS & Banco Santander & Spain & 75.910 \\
\hline & $\mathrm{BP}$ & Bnp Paribas & France & 74.037 \\
\hline \multirow{2}{*}{$\begin{array}{l}\text { Life } \\
\text { insurance }\end{array}$} & ING & ING Group & Netherlands & 40.594 \\
\hline & $A G$ & Aegon & Netherlands & 23.916 \\
\hline \multirow{2}{*}{$\begin{array}{l}\text { Non-life } \\
\text { insurance }\end{array}$} & All & Allianz & Germany & 59.208 \\
\hline & $A X A$ & Axa & France & 45.800 \\
\hline \multirow{2}{*}{$\begin{array}{l}\text { Financial } \\
\text { services }\end{array}$} & GBL & $\begin{array}{l}\text { Bruxelles Lambert } \\
\text { Group }\end{array}$ & Belgium & 12.500 \\
\hline & DB & Deutsche Boerse & Germany & 11.472 \\
\hline
\end{tabular}

Source: Thomson Reuters Statistics

These institutions are used for the calculation of the sectoral indices mentioned previously.

\section{Control variables:}

By analogy with the US market, we will identify control variables related to the European market. Table 7 summarizes the data needed for the CoVaR estimation. 
Table 7: Essential data for control variables, Eurozone

\begin{tabular}{|c|c|c|}
\hline Data & Notation & Source \\
\hline Repo rate for the Eurozone (3 months) & $E U R R_{t}$ & Thomson Reuters \\
\hline Rate of German sovereign bond (maturity) & GerT_Bill ${ }_{t}$ & Thomson Reuters \\
\hline Credit Spread for the Eurozone (10 years) & $E U C D S P_{t}$ & Bloomberg \\
\hline VSTOXX Share Price & \multirow{3}{*}{$P_{t}$} & Thomson Reuters \\
\hline Euro Stoxx Real Estate Stock Market Prices & & Thomson Reuters \\
\hline Stock Exchange Course Euro Stoxx 50 & & Thomson Reuters \\
\hline
\end{tabular}

Source: Thomson Reuters \& Bloomberg Statistics

The control variables are shown in Table 8 .

Table 8: Overview of control variables, Eurozone

\begin{tabular}{|c|c|c|}
\hline Notation & Variable & Measure \\
\hline VSTOXX & VSTOXX & $\ln \left(P_{t}\right)-\ln \left(P_{t-1}\right)$ \\
\hline$E U L Q S P_{t}$ & Liquidity Spread & $\boldsymbol{E U R R}_{\boldsymbol{t}}$ (3months) - GerT_Bill (3months) $_{\mathbf{t}}$ \\
\hline$G B S P_{t}$ & Bond rate variation & 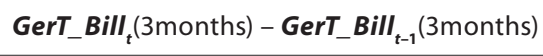 \\
\hline$E U Y D S P_{t}$ & Yield Spread & (10years) - GerT_Bill_(3months) \\
\hline$E U C D S P_{t}$ & Credit Spread (10 years) & \\
\hline ESTX 50 & Return of the Euro Stoxx 50 & $\ln \left(P_{t}\right)-\ln \left(P_{t-1}\right)$ \\
\hline ESRE $_{t}$ & Return of Euro Stoxx Real Estate & $\ln \left(P_{t}\right)-\ln \left(P_{t-1}\right)$ \\
\hline
\end{tabular}

Source: CNB, Authors Calculations

\subsubsection{Model and methodology}

In Section 3, we defined the as the VaR of the institution $i$ conditional on the institution $j$ reaching its VaR level. In our study, the index $i$ is relative to the system and the index $j$ corresponds either to the financial sector (cross-sectoral study) or to the financial institution (inter-company study). This equation is estimated using quantile regression. 
We used the STATA 11.2 software to establish the quantile regression on CoVaR equation (defined in Section 3) also to apply the "two-sample Kolmogorov-Smirnov test" denoted KS and the Ox Metric 7.2 software in order to produce the graphical representations.

\section{Steps of CoVaR estimation:}

The CoVaR is found by following certain steps explained below.

Step 1: Estimate the stock market returns of financial sector indices and financial institutions by the quantile regression ( $q$ is equal to $1 \%$ and $50 \%$ ).

$$
R_{t}^{j}(q)=\alpha^{j}+\delta_{k}^{j} M_{t}+\varepsilon_{t}^{j} \quad \text { With } k=1, \ldots, 7
$$

$R_{j}^{t} \quad$ Yield at the time $t$ of the financial sector (banking, life and non-life insurance, financial services) or financial institutions $j$.

$\alpha^{j}$ constant;

$M_{t}$ denotes the vector of our 7 control variables;

$\delta_{j}^{k} \quad$ represents the coefficient of each control variable $k$ for the sector $j$.

For the US market, the previous equation is rewritten as follows:

$$
\begin{aligned}
R_{t}^{j}(q)= & \alpha^{j}+\delta_{1}^{j} V I X_{t}+\delta_{2}^{j} U S L Q S P_{t}+\delta_{3}^{j} T_{B S P}+\delta_{4}^{j} U_{S Y D S P}+\delta_{5}^{j} U S C D S P_{t}+ \\
& +\delta_{6}^{j} S \& P 500_{t}+\delta_{7}^{j} D_{J U S R}+\varepsilon_{t}^{j}
\end{aligned}
$$

As regards the European market, the equation is as follows:

$$
\begin{aligned}
R_{t}^{j}(q)= & \alpha^{j}+\delta_{1}^{j} \operatorname{VSTOXX}_{t}+\delta_{2}^{j} \operatorname{EULQSP}_{t}+\delta_{3}^{j} \operatorname{GBSP}_{t}+\delta_{4}^{j} \operatorname{EUYDSP}_{t}+\delta_{5}^{j} \operatorname{EUCDSP}_{t}+ \\
& +\delta_{6}^{j} \operatorname{ESTX}_{50}+\delta_{7}^{j} \operatorname{ESRE}_{t}+\varepsilon_{t}^{j}
\end{aligned}
$$

Step 2: Estimate the performance of the system subordinate to the sector or institution $j$, thanks to the quantile regression ( $q$ is equal to $1 \%$ and $50 \%$ ).

$$
R_{t}^{s y s \mid j}(q)=\alpha^{s y s \mid j}+\beta^{s y s \mid j} R_{t}^{j}+\delta_{k}^{s y s \mid j} M_{t}+\varepsilon_{t}^{s y s \mid j}
$$

Where:

$R_{t}^{s y s j}$ system performance at the time $t$;

$\alpha^{s y s \mid j}$ constant;

$\beta^{s y s \mid j}$. measures the contribution of $R_{t}^{j}$ to the system $R_{t}^{\text {system }}$;

$\delta_{k}^{s y s j}$ represents the coefficient of each selected control variable;

$\varepsilon_{t}^{s y s \mid j}$ denotes the error term. 
Step 3: Calculate $V a R_{t}^{j}$ for each financial sector or institution, using only the control variables with significant coefficients in Step 1.

$$
\operatorname{VaR}_{t}^{j}(q)=\hat{\alpha}^{j}+\hat{\delta}_{k}^{j} M_{t}
$$

Coefficients $\hat{\alpha}^{j}$ and $\hat{\delta}_{k}^{j}$ are extracted from equation in Step 1.

Step 4: Calculate $\Delta \operatorname{CoVaR}{ }_{t}^{s y s \mid j}$ with $q$ equal to $1 \%$ and $50 \%$, retaining the significant coefficients $\alpha^{s y s \mid j}, \beta^{s y s \mid j}, \delta_{k}^{s y s \mid j}$ estimated in Step 2 and $V a R_{t}^{j}$ determined by Step 3.

$$
\operatorname{CoVaR}_{t}^{s y s \mid j}(q)=\hat{\alpha}^{s y s \mid j}+\hat{\beta}^{s y s \mid i} \operatorname{VaR}_{t}^{j}+\hat{\delta}_{k}^{s y s \mid j} M_{t}
$$

Step 5: Calculate $\Delta \operatorname{CoVaR}_{t}^{s y s \mid j}$ by determining the difference between $\operatorname{CoVaR} R_{t}^{s y s \mid j}$ with a quantile equal to $1 \%$ and the other with a quantile equal to $50 \%$. This measure assesses the contribution of various sectors or financial institutions to systemic risk.

$$
\operatorname{CoVaR}_{t}^{s y s \mid j}(q)=\operatorname{CoVaR}_{t}^{s y s \mid j}(1 \%)-\operatorname{CoVaR}_{t}^{s y s \mid j}(50 \%)
$$

$\triangle$ CoVaRs are negative because they are calculated from the low yields of the sectors or financial institutions.

As a result, the financial sector (or financial institution) with the largest value of $\triangle C o V a R$ (expressed in absolute value) is the one that contributes the most to systemic risk during periods of distress (crisis).

Step 6: Test the significance of the $\triangle \mathrm{CoVaRs}$ obtained to verify further the ranking of the preselected sectors and financial institutions, according to their contribution to systemic risk.

According to Castro and Ferrai (2013), the significance test aims to identify the sector or institution that is systemically and significantly risky. We examine whether $\Delta C o V a R s$ are statistically 0 (which means that the sector or institution is not systemically risky) or statistically different from 0 (which suggests that the sector or institution contributes significantly to systemic risk).

\section{Contribution of Financial System Components to Systemic Risk: Results}

\subsection{American market}

\section{Inter-sectoral study:}

To evaluate the fit quality of the model, we used the pseudo- $R^{2}$ of the OLS method. In our study, pseudo- $R^{2}$ reach a maximum of $76.95 \%$ and a minimum of $44.66 \%$ with an average of $60.75 \%$, which implies a good specification of the model.

The results of Steps 3, 4, 5 and 6 are given in Table 9. 
Table 9: Systemic risk assessment for financial sectors, USA

\begin{tabular}{l|c|c|c|c}
\hline Sector & VaR $^{j}$ & CoVaR $^{\text {syslj }}$ & $\Delta$ CoVaR $^{\text {sysjj }}$ & $\begin{array}{c}\text { Test KS } \\
(\boldsymbol{p} \text {-value })\end{array}$ \\
\hline Banks & -2.685557 & -1.566132 & -1.546435 & $\begin{array}{l}0.6810^{*} \\
(0.000)\end{array}$ \\
\hline Life insurance & -3.664091 & -2.350383 & -2.350999 & $\begin{array}{l}0.8124^{*} \\
(0.000)\end{array}$ \\
\hline Non-life insurance & -1.896018 & -2.158205 & -2.238386 & $\begin{array}{l}0.8102^{*} \\
(0.000)\end{array}$ \\
\hline Financial services & -1.663418 & -1.774448 & -1.776530 & $\begin{array}{l}0.7277^{*} \\
(0.000)\end{array}$ \\
\hline
\end{tabular}

Note: ${ }^{* * *},{ }^{* * *}$ : coefficient significant respectively at the thresholds of $1 \%, 5 \%$ and $10 \%$.

Source: CNB, Authors Calculations

$V_{a R}^{j}, C_{V a R}^{s y s l j}$ and $\operatorname{CoVaR}^{s y s j}$, calculated with a quantile equal to $1 \%$, are negative and expressed as a percentage. They will be interpreted in terms of absolute value.

The VaR of the life insurance sector displayed the highest loss amount, 3.664091\%, followed in descending order by the banking sector with $2.685557 \%$, non-life insurance with $1.896018 \%$ and financial services with $1.663418 \%$. As an example, we deduce that for a USD 1,000 million investments in the life insurance industry, there is a $99 \%$ chance of not losing more than USD 3,664,091 million.

According to the CoVaRs, the VaR of the system (S\&P 500 ex_Fin) is equal to $2.350383 \%$, meaning that the expected loss of the system is equal to USD 2,350,383 million, in case the life insurance sector loses USD 3,664,091 million . Moreover, the VaR of the system is conditional on the non-life insurance $(2.158205 \%)$, financial services $(1.774448 \%)$ and banking sectors $(1.566132 \%)$. On the other hand, we realize that although the VaR of the banking sector is higher than that of the financial services sector, the failure of the latter leads to a greater loss of the system than that caused by the banking sector failure.

By reference only to $\triangle$ CoVaRs, we find that the life insurance sector ranks first with a maximum equal to $2.350999 \%$, followed in descending order by the non-life insurance sector with $2.238386 \%$, financial services with $1.77653 \%$ and banking with $1.546435 \%$. As a result, life insurance contributes the most to the systemic risk. If this sector reports an estimated loss of $1.896018 \%$, the loss of the system increases by an average of $2.350999 \%$.

Regarding the significance test applied to $\triangle$ CoVaRs by means of the KS test, the null hypothesis, claiming that the sector does not contribute significantly to systemic risk, 
is rejected. With a $p$-value less than $1 \%$, all the selected sectors have a significant impact on the real economy during times of distress.

Figure 2 describes the evolution of $\mathrm{CoVaR}_{t}^{s y s j}$ in the financial sectors: banking (bk), life insurance (li), non-life insurance (nli) and financial services (fs).

\section{Figure 2: Evolution of $\Delta$ CoVaRs of financial sectors, USA}

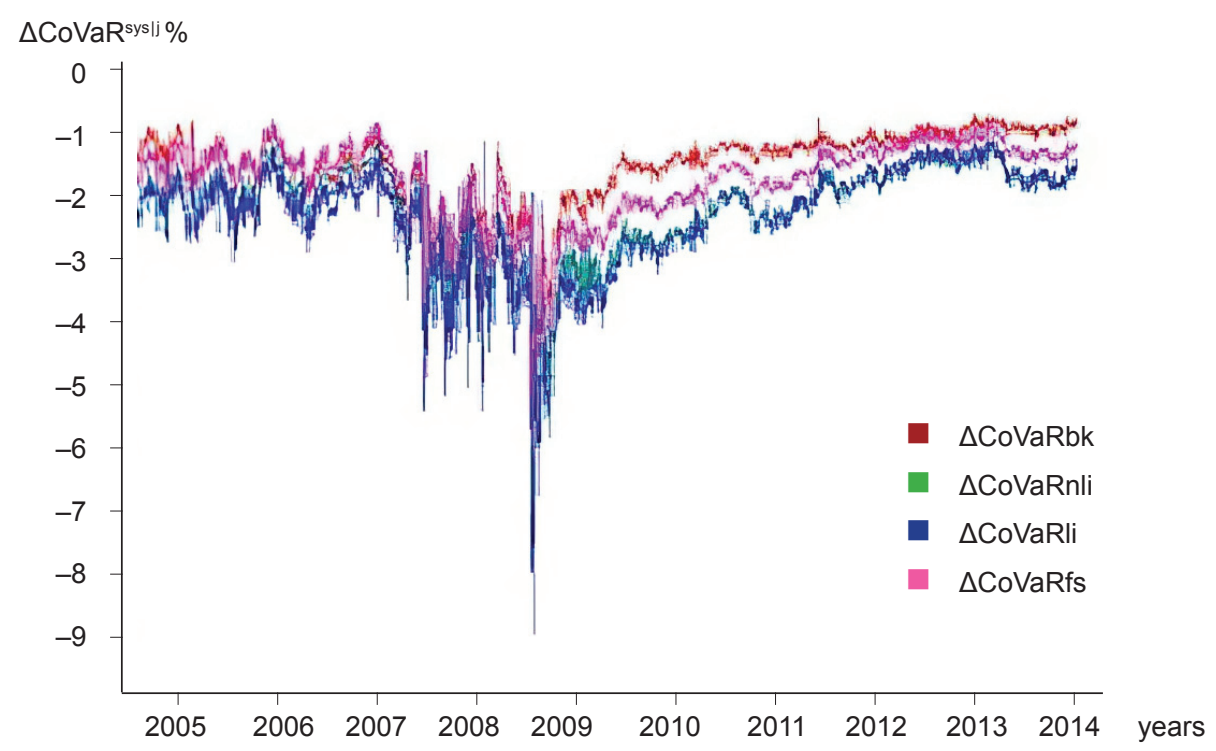

Source: CNB, Authors Calculations

This chart shows, at first glance, that the life insurance sector still contributes the most to systemic risk. Between the end of 2004 and the beginning of 2007, $\triangle$ CoVaRs fluctuated in a relatively stable range. Following the "subprime" crisis in 2007, $\triangle$ CoVaRs began to decline and became more negative; thus, the contribution of the financial sectors to the risk increased. The real economy was therefore going through a very critical period, where the failure of the financial system could lead to huge losses. We see a peak of about $-9 \%$, if the life insurance sector reaches its VaR level. After this fall, $\triangle$ CoVaRs show an upward trend from the beginning of the second half of 2008 until the end of our study period. This can be explained by the reaction of the financial regulatory authorities, who rushed to develop an urgent plan for macro-prudential regulation. The latter has succeeded, as can be seen from the chart examined. 


\section{Inter-company study:}

The pseudo- $R^{2}$ s oscillate between $31.75 \%$ and $71.42 \%$ with an average of $51.68 \%$, which implies a good specification of the model.

Completion of Steps 3, 4, 5 and 6 gives us the results shown in Table 10.

Table 10: Systemic risk assessment for financial institutions, USA

\begin{tabular}{l|c|c|c|c|c|c}
\hline & VaR $^{j}$ & CoVaR $^{\text {sysjj }}$ & $\Delta$ CoVaR $^{\text {sysjj }}$ & $\begin{array}{c}\text { Test KS } \\
(\boldsymbol{p} \text {-value })\end{array}$ & Rate & $\begin{array}{c}\text { Rate/ } \\
\text { MC }^{\mathbf{a}}\end{array}$ \\
\hline JPM & -5.521724 & -1.911472 & -1.909168 & $\begin{array}{c}0.4946^{*} \\
(0.000)\end{array}$ & 2 & 2 \\
\hline WFG & -3.833567 & -1.492767 & -1.591403 & $\begin{array}{c}0.4611^{*} \\
(0.000)\end{array}$ & 5 & 3 \\
\hline MET & -5.18497 & -2.097967 & -2.17895 & $\begin{array}{c}0.5076^{*} \\
(0.000)\end{array}$ & 1 & 7 \\
\hline AIG & -10.05065 & -1.832748 & -1.817201 & $\begin{array}{c}0.4898^{*} \\
(0.000)\end{array}$ & 3 & 8 \\
\hline BH & -1.032772 & -1.272246 & -1.264338 & $\begin{array}{c}0.3397^{*} \\
(0.000)\end{array}$ & 8 & 1 \\
\hline GS & -3.719668 & -1.310401 & -1.308225 & $\begin{array}{c}0.3972^{*} \\
(0.000)\end{array}$ & 7 & 6 \\
\hline AE & -2.770385 & -1.656585 & -1.655386 & $\begin{array}{l}0.4704^{*} \\
(0.000)\end{array}$ & 4 & 4 \\
\hline
\end{tabular}

Note: ${ }^{* * *}, * * *$ : coefficient significant respectively at the thresholds of $1 \%, 5 \%$ and $10 \%$, market capitalization.

Source: CNB, Authors Calculations

Relative to the VaR, the insurance (non-life) AIG records the highest amount of loss, $10.05065 \%$. If it reaches this level, the system loss is equal to $1.832748 \%$. In our sample, it is ranked third, because its contribution to systemic risk is on average equal to $1.817201 \%$.

Taking into account the MC, the insurance (non-life) $\mathrm{BH}$ that holds the largest capitalization is the one with the weakest loss, namely $1.032772 \%$. The VaR of the S\&P 500ex_Fin index is equal to $1.272246 \%$ if this institution is in a state of crisis. BH is ranked last, compared to other institutions where it influences negatively the VaR of the S\&P500 ex_Fin by $-1.264338 \%$ on average. 
We detect that the classification of financial institutions according to the MC does not coincide with that established according to the $\mathrm{CoVaR}_{t}^{s y s \mid j}$. Indeed, the VaR of the system increases by $2.17895 \%$ on average, once the loss of insurance (life) MET estimated is $5.18497 \%$. It should be noted that it is ranked seventh, with a low market capitalization, compared to other institutions.

It is only for the second-ranking JPM Bank and the establishment of the fourth ranked AE Financial Services that we find a similarity.

If JPM struggles and reaches its VaR level of 5.521724\%, the S\&P 500 ex_Fin index will have a VaR which increases by an average of $1.909168 \%$. However, the VaR of the S\&P 500 ex_Fin increases by $1.655386 \%$ if AE reaches its VaR equal to $2.770385 \%$.

Under the KS test, $p$-values below $1 \%$ indicate that all financial institutions selected contribute significantly to systemic risk.

Comparing with the ranking of the financial sectors established in the cross-sector study, we deduce that the life insurance sector contributes the most to systemic risk, followed by the non-life insurance and financial and banking service sectors respectively.

\subsection{European market}

\section{Inter-sectoral study}

It is the same for pseudo- $R^{2} \mathrm{~s}$, which oscillate between $42.92 \%$ and $67.92 \%$ with an average of $56.12 \%$ indicating a quite good specification of the model.

The results of Steps 3, 4, 5 and 6 are set out in Table 11.

Table 11: Systemic risk assessment for financial sectors, Eurozone

\begin{tabular}{l|c|c|c|c}
\hline Sector & $\operatorname{VaR}^{j}$ & $\operatorname{CoVaR}^{\text {syslj }}$ & $\Delta$ CoVaR $^{\text {sysjj }}$ & $\begin{array}{c}\text { Test KS } \\
(\boldsymbol{p} \text {-value })\end{array}$ \\
\hline Banks & -1.373751 & -1.786366 & -1.782948 & $\begin{array}{l}0.7256^{*} \\
(0.000)\end{array}$ \\
\hline Life insurance & -1.554512 & -1.554512 & -1.551701 & $\begin{array}{l}0.7200^{*} \\
(0.000)\end{array}$ \\
\hline Non-life insurance & -1.761402 & -1.537627 & -1.528183 & $\begin{array}{l}0.6971^{*} \\
(0.000)\end{array}$ \\
\hline Financial services & -2.387906 & -1.946019 & -1.942846 & $\begin{array}{l}0.7718^{*} \\
(0.000)\end{array}$ \\
\hline
\end{tabular}

Note: ${ }^{*},{ }^{* *},{ }^{* * *}$ : coefficient significant respectively at the thresholds of $1 \%, 5 \%$ and $10 \%$. Source: CNB, Authors Calculations 
The financial services sector is characterized by the highest VaR, estimated at $2.387906 \%$, followed in descending order by the non-life $(1.761402 \%)$, life insurance $(1.554512 \%)$ and banking sectors (1.373751\%).

Once the financial services sector reached its VaR, the system (SE 600 ex_Fin) reports its expected loss of $1.946019 \%$. Although the non-life insurance VaR $(1.761402 \%)$ is higher than the life insurance VaR (1.554512\%), the system VaR conditional on the non-life insurance sector is low $(1.537627 \%)$, compared to that subordinated to life insurance industry $(1.554512 \%)$. In this sense, we cannot say whether the financial services sector with the highest VaR necessarily contributes the most to systemic risk.

reveal that the financial services sector affects the system VaR negatively, in the event of default, by an average $-1.942846 \%$. Secondly, we are dealing with the banking sector causinga loss of $-1.782948 \%$ to the European economy on average, followed by the life insurance $(-1.551701 \%)$ and non-life $(-1.528183 \%)$ sectors respectively.

The application of the KS test reveals that all the financial sectors contribute to systemic risk significantly.

Figure 3 describes the evolution of $\mathrm{CoVaR}_{t}^{s y s \mid j}$ in the financial sectors: banking (bk), life insurance (li), non-life insurance (nli) and financial services (fs).

\section{Figure 3: Evolution of the $\Delta \mathrm{CoVaRs}$ of financial sectors, USA}

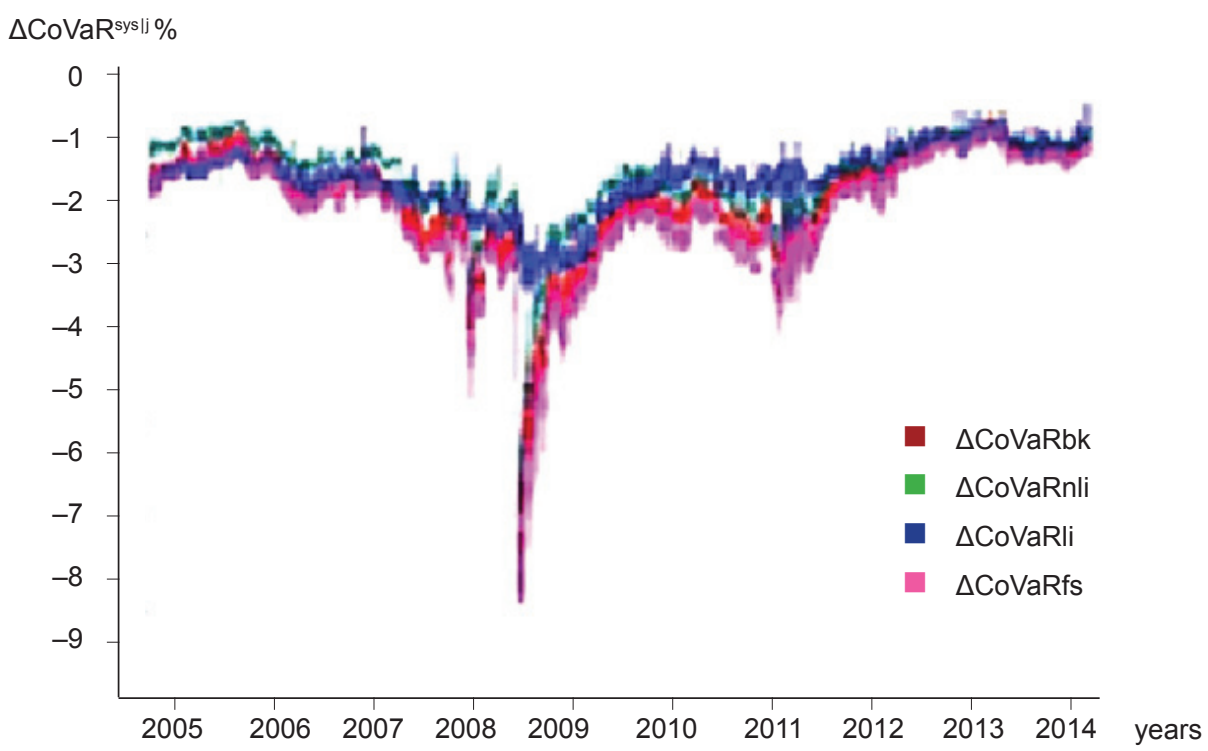

Source: CNB, Authors Calculations 
Figure 3 shows that until the end of 2005, the life insurance sector was the most exposed to systemic risk. Certainly, from 2006 to the end of our study period (the beginning of 2014), we observed that the financial services sector took over, evolving at a pace marked by sharp peaks. This is the riskiest sector from a systemic point of view.

Between the end of 2006 and the end of the first half of 2008, $\triangle$ CoVaRs decline gradually and become more negative. This means a gradual increase in the risk studied. The peak in the financial services sector indicates that the real economy tends to lose even more, about $-6.25 \%$ of the expected loss, when the above sector reaches its VaR level. After this fall, the $\triangle$ CoVaRs move gradually upward until 2010, attesting that the contribution of these sectors tends to decrease, due to the implementation of macro-prudential regulation. Then, they begin to decline again following the crisis of the sovereign debt of the Eurozone that occurred in 2010. We were able to discover a new peak corresponding to the sector of the financial services, estimated about $-3.5 \%$ at the beginning of the second quarter of 2011. The upward phase is immediately resumed and the contribution of the financial sectors to systemic risk begins to fall until the end of our study period.

\section{Inter-company study:}

Pseudo- $R^{2}$ s vary between $41.54 \%$ and $63.44 \%$ with an average of $50.33 \%$, meaning a relatively good specification of the model.

Table 12: Systemic risk assessment for financial institutions, Eurozone

\begin{tabular}{l|c|c|c|c|c|c}
\hline & VaR $^{j}$ & CoVaR $^{\text {sysj }}$ & $\Delta$ CoVaR $^{\text {sysjj }}$ & $\begin{array}{c}\text { Test KS } \\
(\boldsymbol{p} \text {-value })\end{array}$ & Rate & $\begin{array}{c}\text { Rate/ } \\
\mathbf{M C b}\end{array}$ \\
\hline BS & -1.008303 & -1.623259 & -1.620416 & $\begin{array}{l}0.5230^{*} \\
(0.000)\end{array}$ & 5 & 1 \\
\hline BP & -7.037037 & -1.654780 & -1.652536 & $\begin{array}{l}0.5294^{*} \\
(0.000)\end{array}$ & 4 & 2 \\
\hline ING & -9.816358 & -1.549419 & -1.547159 & $\begin{array}{l}0.5156^{*} \\
(0.000)\end{array}$ & 6 & 5 \\
\hline AII & -6.978632 & -1.674680 & -1.672469 & $\begin{array}{l}0.5498^{*} \\
(0.000)\end{array}$ & 3 & 6 \\
\hline AXA & -4.311713 & -1.302144 & -1.298332 & $\begin{array}{l}0.4223^{*} \\
(0.000)\end{array}$ & 8 & 3 \\
\hline GBL & -1.648633 & -1.72579 & -1.726374 & $\begin{array}{l}0.5580^{*} \\
(0.000)\end{array}$ & 2 & 7 \\
\hline DB & -1.007917 & -1.766914 & -1.766302 & $\begin{array}{l}0.5597^{*} \\
(0.000)\end{array}$ & 1 & 8 \\
\hline
\end{tabular}

Note: ${ }^{*},{ }^{* * * * *}$ : coefficient significant respectively at the thresholds of $1 \%, 5 \%$ and $10 \%$, market capitalization. Source: CNB, Authors Calculations 
Thus, we see that ING life insurance records the largest amount of loss, $9.816358 \%$. On the other hand, if its VaR is reached, the VaR of the SE600 ex_Fin index representative of the rest of the European economy (Eurozone) is equal to $1.549419 \%$. $\triangle$ CoVaR $^{\text {sysiNG }}$ shows that the $\mathrm{VaR}$ of the system increases on average by $1.547159 \%$. By limiting ourselves to VaR, ING is ranked first, compared to the other financial institutions. Of course, it becomes sixth according to $\triangle C_{0 V a R^{s y s}[\mathrm{NG}}$.

BS Bank is distinguished by the highest market capitalization. However, it does not systematically contribute the most to the loss of the system, if it is in a state of distress. The VaR of the system increases by an average of $1.620416 \%$, when the VaR of BS equal to $1.0083034 \%$ is reached. We also observe that the classification of financial institutions according to their $\mathrm{MC}$ does not coincide with that established in consideration of $\triangle \mathrm{CoVaR}^{s s s j}$.

$\mathrm{DB}$, which is a financial services company with the smallest market capitalization, is considered the most responsible for triggering systemic risk in the event that its estimated loss of $1.0079174 \%$ is reached.

Regarding the use of the KS test, it is important to emphasize that all the institutions contribute significantly to systemic risk.

Nevertheless, we note that the ranking established during the inter-sectoral study revealed great contribution of the financial services sector to the risk, followed by the banking, life and non-life insurance sectors respectively. This statement is verified with certain reservations at the level of financial institutions.

\subsection{Robustness test}

To further verify the reliability of our results, it seems appropriate to recalculate $\triangle \mathrm{CoVaRs}$ of the financial sectors for the period between 20 August 2004 and 28 February 2014, always keeping the same coverage rate $q=1 \%$, but choosing quantiles different from the median, as recommended by Adrian and Brunnermeier (2011).

From an analytical point of view, the recalculation in question is formulated by the following equation:

The results are given in Table13 and Table 14.

As a result, the ranking of financial sectors already established is maintained for both the US market and the Eurozone.

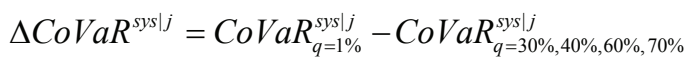


Table 13: $\Delta$ CoVaRs of financial sectors with various quantiles, USA

\begin{tabular}{l|c|c|c|c|c}
\hline & $\mathbf{3 0 \%}$ & $\mathbf{4 0 \%}$ & $\mathbf{6 0 \%}$ & $\mathbf{7 0 \%}$ & Rate \\
\hline$\Delta$ CoVaR $^{\text {sys|BK }}$ & -1.330210 & -1.488213 & -1.564442 & -1.632782 & 4 \\
\hline$\Delta$ CoVaR $^{\text {sys|LI }}$ & -2.200220 & -2.316374 & -2.374618 & -2.462384 & 1 \\
\hline$\Delta$ CoVaR $^{\text {sys|NLI }}$ & -1.719835 & -2.100806 & -2.179941 & -2.249253 & 2 \\
\hline$\Delta$ CoVaR $^{\text {sys|Fs }}$ & -1.351520 & -1.758847 & -1.772485 & -1.827820 & 3 \\
\hline
\end{tabular}

Source: CNB, Authors Calculations

Table 14: $\Delta$ CoVaRs of financial sectors with various quantiles, Eurozone

\begin{tabular}{l|c|c|c|c|c}
\hline & $\mathbf{3 0 \%}$ & $\mathbf{4 0 \%}$ & $\mathbf{6 0 \%}$ & $\mathbf{7 0 \%}$ & Rate \\
\hline$\Delta$ CoVaR $^{\text {sys|BK }}$ & -1.535677 & -1.780514 & -1.780354 & -1.829317 & 2 \\
\hline$\Delta$ CoVaR $^{\text {sys|LI }}$ & -1.342494 & -1.552453 & -1.567225 & -1.726277 & 3 \\
\hline$\Delta$ CoVaR $^{\text {sys|NLI }}$ & -1.311215 & -1.539836 & -1.539798 & -1.674536 & 4 \\
\hline$\Delta$ CoVaR $^{\text {sys|Fs }}$ & -1.765006 & -1.948371 & -1.948584 & -2.104104 & 1 \\
\hline
\end{tabular}

Source: CNB, Authors Calculations

\section{Conclusion}

In our study, we aimed to define the sector and more precisely the institution that contributes the most to the "contagion phenomenon" issued by this type of risk. It was a challenge when we analysed the financial sectors; particularly in that we conducted two-level crosssectoral analyses and inter-company studies.

Commonly, it appears that the sector or institution with the highest VaR does not necessarily contribute the most to systemic risk. Comparing CoVaR to VaR, we found, first, that the sector or financial institution with the highest amount of loss does not necessarily contribute the most to the risk studied. In the light of the findings related to the crosssectoral study, the results show that the life insurance sector contributes the most to systemic risk on the US market, while in the European countries, the real economy is clearly more influential in case a problem arises in the banking and financial services sectors. Regarding the inter-company study, our results reveal that the major financial institutions do not automatically contribute the most to systemic risk, as has been proven by the study by Roengpitya and Rungcharoenkitkul (2011). 
To summarize, we could conclude that for the European markets, the insurance sector leads the most to the occurrence of systemic risk, while for the US market it is both the banking and the financial services.

Moreover, we have been able to admit that the size criterion can be an effective source of error for financial regulators. Indeed, it has been shown that smaller institutions are likely to have negative impacts on the real economy than those classified as large companies. It is therefore essential to explore the most risky institutions systematically in consideration of other criteria, such as substitutability, complexity, interdependence or cross-border activities.

\section{References}

Adrian, T., Moench, E., Shin, H. S. (2008). Liquidity, Monetary Policy, and Financial Cycles. Current Issues in Economics and Finance, 14(1).

Barr, M. S., Jackson, H. E., Tahyar, M. E. (2016). Financial Regulation: Law and Policy, Chapter 1.1-Finance Today. U of Michigan Law \& Econ Research Paper No. 16-014.

Barr, M. S., Jackson, H. E., Tahyar, M. E. (2016). Financial Regulation Law and Policy. Foundation Press, pp. 691-719. ISBN 978-1634592956.

Basel Committee on Banking Supervision (BCBS) (2011). Global Systematically Important Banks: Assessment Methodology and the Additional Loss Absorbency Requirement.

Basel Committee on Banking Supervision (BCBS) (2017). Basel III Transitional Arrangements 2017-2027.

Basel Committee on Banking Supervision (BCBS) (2020). The Basel Framework. Basel: Bank for International Settlements.

Baur, D. G. (2012). Financial Contagion and the Real Economy. Journal of Banking \& Finance, 36(10), 2680-2692, https://doi.org/10.1016/j.jbankfin.2011.05.019

Benli, V. F., Mastourı, S. (x). Evaluation of Systemic Risk between American and European Financial Systems. book of, 40.

Bernal, O., Gnabo, J. Y., Guilmin, G. (2014). Assessing the Contribution of Banks, Insurance and other Financial Services to Systemic Risk. Journal of Banking \& Finance, 47, 270-287, https://doi.org/10.1016/j.jbankfin.2014.05.030

Bilger, M. (2016). Finalisation de Bâle III-Bâle IV : les termes de l'accord à la loupe, Revue Banque N`815.

Borio, C., Drehmann, M., Tsatsaronis, K. (2014). Stress-testing Macro Stress Testing: Does it Live up to Expectations? Journal of Financial Stability, 12, 3-15, https://doi.org/10.1016/j. jfs.2013.06.001

Castro, C., Ferrari, S. (2014). Measuring and Testing for the Systemically Important Financial Institutions. Journal of Empirical Finance, 25, 1-14, https://doi.org/10.1016/j. jempfin.2013.10.009 
Deloitte-Emea Centre for Regulatory Strategy (2013). Addressing the Risks posed by Systemically Important Banks, The End of too Big to Fail? London: Deloitte, p. 13.

Dowd, K. (2005). Measuring Market Risk. John Wiley \& Sons.

Duffie, D. (2010). How Big Banks Fail and What to Do about It. Princeton University Press. Available at: https://web.stanford.edu/ duffie/DuffieDealersMarch10.pdf

Duffie, D. (2011). How Big Banks Fail, And What to Do about It. Princeton, New Jersey: Princeton University Press. ISBN 9780691148854.

Freixas, X., Laeven, L., Peydro, J. L. (2015). Systemic Risk, Crisis, and Macroprudential Regulation. Cambridge, MA: MIT Press. ISBN: 9780262028691

Gauthier, C., Lehar, A., Souissi, M. (2012). Macroprudential Capital Requirements and Systemic Risk. Journal of Financial Intermediation, 21(4), 594-618, https://doi.org/10.1016/j. jfi.2012.01.005

Jacob, H. (2017). Bâle IV : Vers Une Révısıon De L'exıgence De Fonds Propres, Formation Banque Finance, l'AFGES. Available at: http://www.afges.com/ bale-iv-vers-revision-de-lexigence-de-fonds-propres/

Mishkin, F. (2008). Systemic Risk and the International Lender of Last Resort. BIS Review, 109, 1-7.

Racicot, F. É., Théoret, R. (2006). La Value-at-Risk: Modèles de la VaR, simulations en Visual Basic (Excel) et autres mesures récentes du risque de marché. No. UQO-DSA-wp022006). Département des sciences administratives, UQO. Available at: https://pdfs. semanticscholar.org/39a1/390056c844394f2061c6ee71bb69c3709bf6. pdf?_ga=2.252117001.1422950398.1594630784-2076459301.1594630784

Roengpitya, R., Rungcharoenkitkul, P. (2011). Measuring Systemic Risk and Financial Linkages in the Thai Banking System. Systemic Risk, Basel III, Financial Stability and Regulation, https://doi.org/10.2139/ssrn.1773208

Schwaab, B., Lucas, A., Koopman, S. J. (2011). Systemic Risk Diagnostics: Coincident Indicators and Early Warning Signals, https://doi.org/10.2139/ssrn.1773524

Staff of the IMF and the BIS, and the SFSB (2009). Guidance to Assess the Systemic Importance of Financial Institutions, Markets and Instruments: Initial Considerations. Report to the G-20 Finance Ministers and Central Bank Governors, 6-9. Available at: https://www.imf.org/external/np/g20/pdf/100109.pdf 